\title{
Shifting Identity from Within the Conversational Flow of Organisational Complexity
}

\author{
Alfredo Ortiz Aragón
}

\begin{abstract}
This article draws on an organisational strengthening process I carried out as part of my PhD research, which was intended to develop capacity-building methodology to help organisations grapple with their complex social change realities. Focused on conversations generated in two methodological moments in a particular workshop, I share how co-researcher Juan Carlos Giles and I used systemic methodological experimentation to generate critical organisational conversations in order to support an organisation's desire to strengthen its identity. I use Stacey, Griffin and Shaw's 'complex responsive processes' and Checkland's 'soft systems thinking' to explore relationships between the methodology and the conversations that emerged, and Reason's 'choice and quality' framework to explore implications for action research.
\end{abstract}

\section{How change emerges through complex responsive processes of human interaction and power relating}

For the purpose of this article, a complex situation is any situation in which multiple actors, with multiple motivations and perceptions, combine with an unknowable mix of factors to affect how change occurs (Flood 1988). In these situations, change emerges and is not caused, predictable or controllable by any particular actor, including 'organisations' and their interventions (Burns 2007; Checkland 1981; Flood 1999; Midgley 2000; Snowden and Boone 2007; Stacey 2007). In this article I draw on a particular interpretation of complexity theory called Complex Responsive Processes (Stacey 2007, Stacey et al. 2000), which posits that overall patterns of activity (i.e. population-wide patterns) 'emerge in the interplay' of the desires, intentions and actions of all of the individual persons and groupings of people in a given social setting (Stacey 2007: 303). Some of these actors, such as individuals, local organisations, nongovernmental organisations (NGOs), governments, and businesses may plan and act with intent in expectation of realising some future desirable outcome, while others may simply be concerned with 'getting things done' in their day-to-day lives. But since different actors in a given social setting have different desires and intentions, as well as different levels of resources, 'The interplay of intentions is essentially a conflictual process, in the sense of ongoing exploration and negotiation, taking the form of co-operation or manipulation, and sometimes hostility, aggression, competition, revolution or war'(Stacey 2007: 303). In this ongoing exploration and negotiation unless a given actor has control over the intentions, desires and action of all the actors that come to bear on a situation, that actor cannot control the pattern of activity that emerges, nor can any plan or blueprint predict that outcome. Patterns of activity emerge in complex environments via the conflictual interplay of desires, intentions and actions of multiple actors with different levels of symbolic and material resources, and no one actor can be in control of or even fully understand that interplay (Flood 1999; Stacey 2007).

The idea of non-linear change emerging from multiple factors has been around for a long time, in traditions such as systems thinking (von Bertalanffy 1968; Checkland 1981; Churchman 1979; Flood 1988), organisation development and strategy (Snowden and Boone 2007; Jackson 2003; Mintzberg and Waters 1985; Morgan 2006; Mintzberg et al. 2009), and more recently in

IDS Bulletin Volume 43 Number 3 May 2012 (c) 2012 The Author. IDS Bulletin (C) 2012 Institute of Development Studies Published by Blackwell Publishing Ltd, 9600 Garsington Road, Oxford OX4 2DQ, UK and 350 Main Street, Malden, MA 02148, USA 
development studies (Burns 2007; Chambers 1997, 2010; Ramalingam and Jones 2008) and capacity development (Baser and Morgan 2008; Kaplan 1999; Land et al. 2009; Morgan 2005; Taylor and Clarke 2008). What makes complex responsive processes different is it provides a theory of how complexity is generated through local communicative interaction between socially conditioned (but not determined) people with differing levels of power.

Communication in complex responsive processes is thought of as one body making a gesture to another body, which in turn evokes further responses (Stacey 2007: 271). In the back and forth gesturing each body simultaneously interprets and constructs, shapes, enables and constrains the meaning that dynamically emerges from the interaction. As such, meaning exists as part of a social act. As meaning emerges in conversation we can sometimes anticipate or predict where a conversation is going, as well as shape where we would like it to go. To anticipate where conversation may be emerging requires the ability to interpret the meanings of the body language, sounds, inflections, colours and even smells of the participants in the conversation. This involves taking into account the attitude of the other, including entering into the emotions that are expressed in a conversation. Gesturing processes are embodied and are central to understanding how we 'know' anything (ibid.: 273). The communication referred to in this article, therefore, includes the full range of gestures that are exchanged between bodies and which generate meaning.

As people in a given social setting gesture back and forth while pursuing their desires and intentions, population-wide patterns of activity emerge due to the constraints placed on participants as they communicate. Stacey, borrowing (as an analogy) from the concept of complex adaptive systems consisting of heterogeneous agents, explains how novel patterns may emerge depending on the quality of the connections between actors:

... evolving, coherent, population-wide patterns do emerge in local interaction between agents when those agents are richly connected to each other, so imposing conflicting constraints on each other, and when they differ sufficiently from each other, so displaying diversity. When these conditions are met... the patterns of movement over time... [may] take the form of regular irregularity (edge of chaos), which has the property of amplifying small differences into novel patterns (Stacey 2007: 303-4).

Constraints are imposed as different participants in any given conversation hold and exercise different degrees of charisma, knowledge, social position, eloquence, moral authority, controlling behaviours, control over resources and opportunities, access to others, and other symbolic and tangible resources of power. Constraints may include social control that participants impose upon themselves when they internalise and follow societal norms of behaviour or norms of behaviour specific to a particular social setting such as an organisation, a church gathering, or a dinner party (ibid.: 312 ). This may include self-censoring by less-powerful individuals as they communicate with more powerful individuals, or vice versa, as participants gesture and respond in complex social acts conditioned by locally relevant norms of interaction. As people engage with each other in communicative action - conditioned but not determined by the rules of the game imposed by cultural norms and power relationships - unpredictable chemistry and meaning emerge that constrain people's motivations and intentions. ${ }^{1}$

But as diverse actors reflect on these norms, power relations and broader population-wide patterns of activity, these can be challenged through conversation, generating the potential for transformational effects on future patterns that emerge, even as participants cannot know what these patterns will be in advance.

\subsection{Changing patterns of conversations in organisations}

Organisations, as social settings, are themselves patterns of interaction between interdependent people (Stacey 2007: 286). An organisation is a reified social collectivity which is 'essentially a conversational process in which the world is interpreted in a particular way which legitimates shared actions and establishes shared norms and standards' (Checkland and Holwell 1998: 71). The dominant patterns or tendencies in this communication not only constrain, as noted earlier, but also enable movement into the future (Shaw 2002). These 'enabling-constraints' exist as power relations between people in interaction who are socially conditioned by their life experiences and situational motivations. 
The settings in which we explore change can be more constraining than enabling (Shaw 2002: $45)$, in part because there is no singular, collective understanding of the organisation, its contexts and aims, but rather multiple understandings based on the interests and agendas of individuals, sub-groups, as well as overall 'official' accounts of the organisation (Checkland and Holwell 1998: 83). The existence of different interests and agendas means that groupings of people in organisations have to constantly navigate accommodations between conflicting interests in order to promote coherent collective or 'organisational' action (ibid.).

Shaw explains that since enabling-constraints are generated through communicative action, 'the act of conversation itself is the key process by which forms of organizing are dynamically sustained and changed' (ibid.: 10, italics added). Whereas repetitive conversations may block the emergence of innovative strategies, more fluid forms of conversation may be more amenable to influencing organisational change (Stacey 2007: 286). Disturbing repetitive patterns of conversation so that new ones may emerge is therefore key for enabling organisational change (Shaw 2002: 34). But the precise outcome that results from disturbing these patterns will emerge from the influences and intentions of all of the actors involved as they continually shape and shift the web of enabling-constraints in which they are enmeshed. All actors are not motivated by a single, universally understood vision or a set of goals, but by their own interpretations of the options that are available and sensible to them in their evolving circumstances as they communicate (ibid.: 51). As such only from within the emergent, changing flow of everyday communicative interaction can enabling-constraints be influenced so that new patterns of interaction may emerge. To enter the flow of ongoing conversation (i.e. complex gesturing) is to enter the streams of organisational complexity. From within, significant shifts in conversations may represent transformations in organisational patterns of activity, and therefore, organisational identity.

I now share how elements of complex organisational identity emerge, are challenged, reinforced (i.e. validated), and in some cases shifted through the communicative action of conversation.

\section{Strengthening the identity of a militant organisation \\ 2.1 Focus of the action research with the Program for Democracy and Global Transformation}

The Program for Democracy and Global

Transformation (PDTG, Programa Democracia y Transformación Global) is a self-described militant, activist organisation working for social justice, with a strong political agenda focused on changing uncritical, hegemonic ways of seeing the world and development intervention in the world. Strong within its members' identities is the need to challenge what they perceive to be the inequitable status quo and propose alternatives to neoliberal, Western capitalist, paternalistic, sexist, structurally unjust power systems and cultures. They approach their work through the concept of 'weaving knowledges', which means finding ways to connect critical sociological and anthropological theory from academia with local knowledges, practices and world views of actors engaged in social movements in ongoing challenges in Peru and Latin America. They do this through editing and publishing academic pieces that critically analyse current development conflicts (e.g. see de Echave et al. 2009; Escobar 2010; Hoetmer 2009; de Sousa Santos 2006; Vargas Valente 2008; Zibechi 2007), as well as by accompanying and strengthening the capacities of key organisations working within social movements - for example women's and indigenous groups. A core assumption underlying PDTG's work is that social movements offer an important alternative to hegemonic development thinking and practice, and by accompanying and strengthening key organisations in social movements, much can be understood about the active struggles of oppressed people in their dynamic local realities. This can provide evidence of development alternatives, whereas critical theory can enable transformational praxis within social movements. The accompaniment and strengthening work is mainly done via the programmatic area Noqanchiq, meaning 'We, together', and the critical research and publishing work by the programmatic area Tejiendo Saberes² (literally, 'Weaving knowledges').

The focus of the overall Action Research process was to help PDTG develop a shared organisational identity via the identification, recognition and valuing of individual and collective capacities and challenges. The purpose 


\section{The actors}

The following people participated in the two workshop moments.

Tejiendo Saberes ('Weaving knowledges'): Rapha Hoetmer (Director), Álvaro Maurial (Publications Coordinator), Miriam Castro (Publications Marketing and Distribution), Gina Vargas (Board President)

Noqanchiq ('We, together'): Mar Daza (Programmatic Lead), Diego Saavedra (Organisational Development Facilitator), Patty Manriquet (same)

Comunicacion Alternativa ('Alternative communication'): Mary Soto (Professional Communicator), Felix Álvarez (same)

of the specific 'Cluny' workshop that this article draws from was to develop an organisational theory of change that would help clarify the boundaries between PDTG's identity as a political collective versus a more structured social change organisation that carries out projects. In the remainder of this section I share narratives from two important methodological moments in the workshop: sociodramas and theories of change developed by programmatic area (also referred to as teams).

\subsection{Sociodramas depicting organisational relevance Methodology ${ }^{3}$}

The sociodrama (i.e. skit) exercise took place in several moments over one afternoon and the following morning and included preparation, feedback and reflection activities. Our intention was to generate creative tension between the programmatic offerings of each team and the expectations and perceived value of those offerings by the intended primary stakeholders. This would generate assumptions about the relevance of PDTG's programmes to be used in developing theories of change later in the workshop. In the absence of the actual primary stakeholders, we generated a simulation that would at least attempt to shake out some differences between stakeholder motivations/ expectations and PDTG programmatic intentions. The following methodological details are important for understanding the exercise:

- Each team first carried out a critical introspection exercise regarding their programmatic relevance with their target stakeholders. This built on an exercise done a month earlier in another workshop (Playa Arica) in which each team had developed analysis regarding 'Who we are, what do we do, and what do we want as a team?'. In reference to this last question we asked them to answer 'Why is what you want important, and to whom is it important?'. We also asked each team to generate questions regarding their programmatic offering that they would ask of their target stakeholders if they were present.

- Each team was to design their sociodrama to show how the work they do is important, as well as to show 'What are the behaviours and motivations (visible or hidden) of the people involved in this work (i.e. "them" and "us")'.

- Feedback was generated in conversational plenary sessions, enhanced by comments and questions registered at various moments on Post-It notes.

\section{Sociodramas}

Team Tejiendo Saberes

Tejiendo Saberes (TS) was represented by Rapha, playing himself as Director of PDTG, and Álvaro playing Jorge, a professor from a community in the Andean highlands.

Act 1: Rapha introduces himself to Jorge, who expresses that his community's conflict with a mining company needs to be made more visible to the local and regional governments, as well as 'the folks in Lima'. Jorge explains that his community organisation wishes to carry out neighbourhood consultative process throughout the Province to convince others to support a Provincial referendum to stop the mining project. He also would like to carry out workshops with local authorities to generate their support for the referendum. He asks Rapha if PDTG has experience in these areas.

Rapha begins by mentioning PDTG's positive relationship with CONACAMI (The National 
Confederation of Peruvian Communities Affected by Mining) and notes that PDTG is an organisation that carries out projects, but which is also committed to working with social organisations 'on the ground'. He proposes that PDTG help in two ways (though it turns out to be more). First, they would organise key activists in Lima to present the issues and generate feedback. He could also give some copies of the PDTG-published cartoon booklet Of Course, the Territory is Ours to distribute at the community level. He suggests that it would be interesting to carry out a joint systematisation process to better document the conflict with Jorge's community, because that could produce relevant knowledge for other struggles as well. Lastly he offers to accompany Jorge's organisation over the following months, participate in the protests, and carry out training workshops. From there, they could decide what to do next.

Act 2: Rapha and Álvaro are marching in a protest yelling 'Agriculture yes, mining no, agriculture yes, mining no, referendum now!' Suddenly Rapha yells that the police are coming to put down the protest, at which point they quickly disperse and then run off the scene.

Act 3: Rapha once again comes across Professor Jorge and updates him that PDTG has documented and communicated everything that has transpired, as well as initiated trainings through PDTG's Noqanchiq team. He asks how everything has gone since the protest, which he heard had resulted in his (Jorge's) temporary imprisonment and torture. Jorge shares that after all the effort they have won approval for the anti-mining referendum and he thanks Rapha for his support. He requests further support for the referendum in the form of video documentation, training and a publication as an input to the training. The publication should help identify theoretical arguments to support a rejection of mining, and include testimonies of teachers, mayors, parents, rural women and others that are part of this struggle.

Act 4: After some time Rapha again meets with Jorge, and as he says hello he hands him a draft copy of the publication, highlighting how the book comes with a PowerPoint presentation with maps and photos to share in the public forum which will take place in a month. He insists that it is 'a practical book' with interviews and pictures that accurately represent everything that has transpired, and asks if it could be presented in the public forum. The skit ends with both saying: "On to the assembly then!"

Team Noganchiq

Diego, Mar, Patty and Mary participated in this skit, with the audience involved as well. Diego begins by briefly explaining that the primary mission of Noqanchiq is accompaniment of organisations that work in social movements, including CONACAMI, different women's and indigenous rights organisations, and various popular education, critical art and alternative communications organisations. The sociodrama takes place in a single act, with Patty facilitating a workshop on behalf of PDTG to define the characteristics of the ideal female leader with members of a women's organisation.

Act 1: With participants seated on the ground, Patty asks for a volunteer to stand next to her so that the participants can stick the characteristics of an ideal leader directly onto the volunteer's body - wherever they most make sense. 'Diega' volunteers and the participants begin to write and arrange ideas on her body (see Figure 1). 'Fair', placed on her heart; 'Strong, to combat the oppressors', also on her heart; another 'Strong', placed on her shoulder 'so that she packs a punch!'; 'Solidarity, with her fellow companions and other social movements', placed on her hand.

Suddenly the leader of the organisation, Juana, gets up and excuses herself, saying she has to attend to the food because it's not properly organised. Patty reminds her that this is her process and that she should be participating, but Juana simply states she is confident with the facilitators' abilities and to please continue without her until she returns in an hour and a half. Juana leaves and Patty asks the participants what should be done - continue, suspend, wait? stating it is their responsibility to decide. In the conversation that ensues, one person suggests that the facilitators decide, another that Juana be removed of her leadership duties, and yet another that the group deal with it more responsibly - as a bump in the road in an ongoing process. One participant, ignoring it all, stands up and places the word 'Lucid' on Diega's face: 'That she be able to speak well - decisive and strong - like Juana!' 


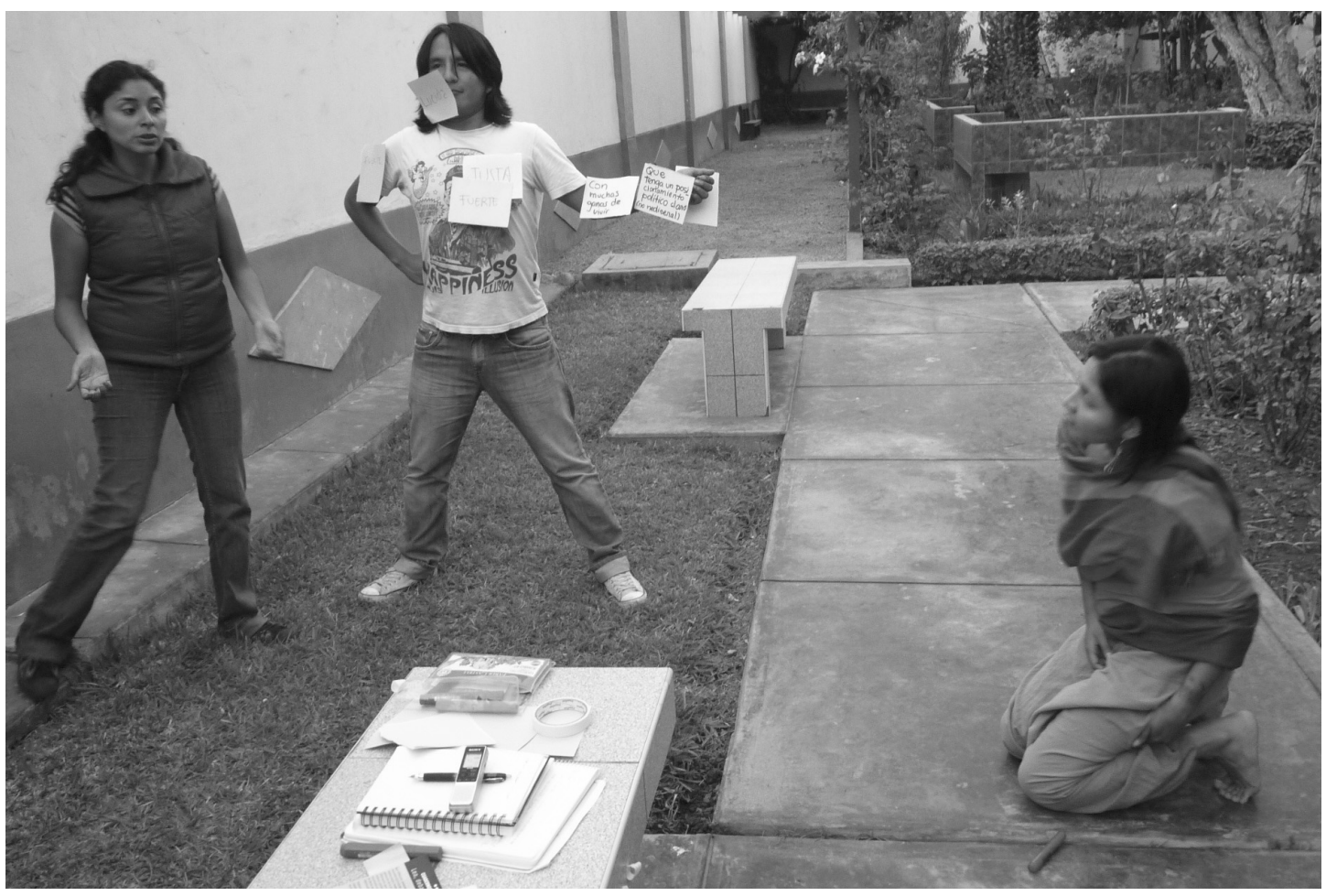

Juana returns stating she was able to get everything in order and Patty immediately confronts and informs her that they have had a long discussion about her inopportune exit, to which Juana responds: 'Thank you for bringing this up, which is very good timing because I would like to share a few thoughts of my own on the matter'. She proceeds to scold the women participants who were on the meal planning committee for not doing their job properly in the first place. She acknowledges that she should be participating in the workshop - this, in spite of her vast experience - but explains that when the other 'compañeras' don't do their job she is forced into this difficult situation. She thanks PDTG for facilitating spaces like these to talk about things that normally aren't discussed, or are discussed very superficially in big assemblies. Patty concludes by suggesting a future workshop to develop strategies to put the identified attributes to practice. Applause...

\section{Discussion of key themes as they relate to organisational identity}

Academic theory and social movement practice - is Tejiendo Saberes attempting to connect unbridgeable worlds? In the initial round of activity in preparation of the sociodramas the internal dialogue within the
TS team revealed an unresolved tension regarding the usefulness of the theory generated by TS to key actors in social movements. On the one hand TS substantiated its programmatic offering 'Research with, from and for social movements' as being relevant because it makes visible potential development alternatives present in the actions, theories and proposals of social movements. 'We assume this is relevant to ourselves, the women's and campesino movements, and the sexual diversity movements' (TS team). And for its publications programmatic offering (e.g. books on community and social movement resistance to mining, indigenous rights, etc.) the TS team offered the following substantiation:

We think it is important to develop and distribute products that document social conflicts and resistances, to provide a visible memory of these events and help us learn from them in relation to broaden contexts. The book Mining and Territory, for example, captured voices and visions from the front lines (i.e. from indigenous leaders, researchers, militants) and contributed to broader theoretical/academic debates. We think this is primarily relevant to CONACAMI. 
But in the second part of the exercise they formulated questions to CONACAMI and other actors in social movements that put those same offerings in doubt, as well as raised doubts about the usefulness of progressive academics to the on-the-ground work of social movements:

- To what extent do our research publications and seminars provoke discussion and strengthening in your movement?

- To what extent does our research question Eurocentric hegemony on critical theory and generate paradigms and theories based on alternative realities in Peru?

- Do you see PDTG's publications and seminars as different from the hegemonic academia? How, why?

- What research methodologies and languages are appropriate between academia and social movements?

- How do international networks of progressive researchers and activists contribute to resistances in Peru?

This questioning goes deeper in a postsociodrama plenary session when Diego asks if the theoretical dispute is only about content, or if it is also about the ways in which knowledge is produced. In that same conversation Mary insists that knowledge production with actors in social movements should not only serve to generate better elements to support external theoretical disputes, but to help better understand local realities and needs. These reflections are further supported by questions registered on Post-It notes towards the end of the exercise: 'How can we make theories and texts be more accessible to social movements and not only to the academia? Does the theoretical dispute include the ways knowledge is produced? Is theory different from knowledges? Should epistemological alternatives not open new horizons and challenge the existing dominant ways of doing things?'

Through the questions and conversations participants are actively constraining the field of possibility, challenging the very legitimacy of 'weaving knowledges' as a concept - a bridge between critical theory and social movement practices. Is TS trying to join concepts that can be bridged (i.e. theory and practice) with forms of production that may be incompatible? - i.e. theoretical construction about social movements generated through hegemonic academic rules and practice which yield information that is unusable or irrelevant to actors in social movements.

In response the TS team uses the sociodrama to legitimate a bridge between these different worlds by making its publications more practical and useful for the community organisation. Rapha offers a colloquial publication (the cartoon booklet), and when he meets Jorge in a later scene he presents him with a 'practical' didactic publication and PowerPoint, with maps and pictures to present in the assembly, relevant to the local situation. Rapha is in essence responding to the very relevant questions posed pre- and post-skit. TS's incorporation of these new strategies in the sociodrama shows their belief that these bridges are possible and feasible - even to the extent of communities in the future desiring 'the theoretical arguments to support our rejection of mining!'

Noganchiq - in search of new methodology and capacities for strengthening political actors in complex situations

The Noqanchiq team developed critical questions and some hypothetical answers (in italics) to ask of their primary stakeholders to guide their analysis on the relevance of their programmatic offering:

- What changes are needed for you to be able to strengthen your leadership and your work with communities?

- What do we think they understand about what we do... and why do they wish to be strengthened (a question to themselves as a team)? 'We think that for some the motivation for participating in this process is that it brings international recognition.'

- How have the dialogues we have sponsored with the women's movements generated impacts in the women's organisations and in individual women's lives? 'We think it has helped us get to know the women and their resistances better, as well as generate less negative perspectives about feminists from within the women's movements. But after the dialogues, what?'

The questions Noqanchiq ask of themselves reveal that they are barely forming their identity as a team; the Post-It notes and plenary reflections confirm this: 'What do these organisations really want from PDTG? Do we understand the 
organisational and structural dynamics of these movements? How do we manage power relationships with organisational leaders? How do concepts such as training, strengthening and accompaniment connect to transformation? How do we make accompaniment a daily practice and what rate of change do we expect to support through accompaniment?'

The main elements that emerge from the questioning and the subsequent conversations can be summed up in two main items. First, significant questioning is levelled regarding the real motivations and interests of the social organisations with which PDTG works. The question 'Do we really know what these organisations want, including their hidden agendas?' captures this issue well. This leads to a litany of additional examples of half-hearted participation of primary stakeholders in PDTGfacilitated processes, including those facilitated by TS. Various hypotheses are then offered for the inadequate participation:

- Lack of commitment because they are used to instrumental relationships with NGOs?

- Lack of capacity to carry forward their own processes?

- An intentional and smart outsourcing to experts for things outside organisational expertise?

- PDTG intentionally reserving certain roles for itself through paternalistic behaviours?

Lastly, they discuss being at a loss for methodology that helps them generate a culture of accompaniment, construct democratic, collaborative and equitable relationships, and generate changes in the political culture of these organisations. This includes questioning their own basic understanding of concepts such as accompaniment and systematisation. 'What capacities do we have as a team?' becomes an important discussion point.

Identity implications PDTG's hybrid 'bridging' identity is in question

In the Noqanchiq sociodrama knowledge is generated for the practical purposes of improving organisational leadership. In other moments team members speak of the importance of systematisation of experiences, but again this is for practical purposes of strengthening capacities and generating useful local knowledge, and not to generate theory. The TS team, on the other hand, is very intentionally trying to generate a bridge between critical theory and social movement practices. But various participants, including members of TS, generate pushback on this concept through the sociodrama exercise, with some participants, such as Mar, making very direct challenges: 'Are we a connection (i.e. bridge) or are we militants, or are we who we are and that is developed along the way and has various sources? This area of our identity needs a lot of reflection'. These pushbacks include:

a challenging the idea that locally generated knowledge should be generated primarily for use in theoretical debates elsewhere; rather, that it should be used to support local sensemaking processes;

b challenging the idea that externally generated knowledge can even be useful in specific local struggles - in content and form; and

c challenging the idea that progressive academics have the epistemological tools, world views and dispositions to co-generate local knowledge in ways that honor diverse local knowledge and world views.

These dilemmas remain unresolved even as the TS sociodrama conceptually resolves some of the issues that are being challenged by offering practical products that include theoretical arguments.

On a smaller scale Noqanchiq's identity is also in question as - after reflecting on Juana's resistance - they enunciate their frustrations and fears about the motivations of the organisations they accompany, about the complexity of the changes they are trying to support, and about their own need for better methodology and team-level capacities. At one moment this leads to a clarification by Diego that 'We don't only want to serve the social movements from their perspective, but should look at them more critically'. This same notion had been mentioned earlier by Rapha, and is now further developed by Mary:

We need to be more precise here because not every social movement is a transformational entity. For example, some of these movements put forth the Andean indigenous theme as an ideal for society... But it is one thing to recover cultural practices and quite another to base your action on regressive ideas that are sexist and hierarchical, and that deep down also have 
a racial undercurrent that rejects diversity. Some of our friends in the indigenous movements consider diversity to be an aberration; they are movements that do not accept change - they don't accept it!

Mary suggests that PDTG should only support movements that actually have emancipatory causes and embrace diversity as a core value. We will see that this shift in conversation subsequently becomes a core element in Noqanchiq's identity as expressed in its theory of change.

\subsection{The development of 'systemic' theories of change Methodology}

This exercise was meant to produce conceptual justifications in the form of 'conditions' needed for change (and underlying assumptions) and then to generate dialogue between those justifications and desired organisational action. Each team identified a core idea that reflected the types of transformations they are trying to support, the 3-5 most important conditions that would need to exist for these types of transformations to be possible, and the most important conceptual relationships that exist between the conditions. Each team then developed a mind map that figuratively places the entire conditions diagram in the middle of the map and carried out the following analyses on the branches:

a The most important types of interventions that this analysis implies for PDTG;

b The specific roles and capacities that these actions imply for PDTG;

c The most important relationships that this implies with other actors outside of PDTG and with other teams within PDTG.

Discussion of key themes as they relate to organisational identity

Noqanchiq takes a pro-diversity stance

The Noqanchiq team generated four conditions and a purpose statement which expressed their intention to critically question the internal practices of key organisations that support social movements. The following condition expresses this desire the most clearly: 'Organisations [in social movements] recognise and accept how the same systems of domination, exclusion, exploitation and discrimination they are struggling against exist within their organisations, and take this into account in their proposals for change'. This condition is meant to support the emergence of 'a truly democratic organisational and political culture which questions, proposes and practices alternatives to authoritative, patriarchal, colonial, racist, sexist, capitalist, fundamentalist systems that promote hegemonic ways of thinking, exploitation and the destruction of nature'. In other words, Noqanchiq believes broader transformations occur when key actors and organisations in social movements first reform from within. This includes recognising dominant population-wide patterns of behaviour that they enact through their communicative activity. Only by doing so can they serve as real alternatives and not simply reproduce hegemonic ways of thinking and acting.

This has important methodological implications that team Noqanchiq then proposes.

Transformation from within requires a new level of concentisación, or self-awareness, which allows for new world views which favour diversity including tolerance of other social movements to emerge. Deeper self-awareness can best be supported through practices of reflection in action that allow people to introspect and explore their beliefs and fears at a deeper level. This leads to Noqanchiq interventions focused on:

- 'Critical accompaniment, i.e. using reflexive methodologies to strengthen capacities while challenging dominant ways of thinking'; and

- 'Facilitation of dialogue between organisations and other change agents from different movements to challenge prejudices and develop common ground'.

This implies political and methodological capacities that allow Noqanchiq to open sensibilities and generate empathy through accompaniment, now defined as: 'Co-facilitation of transformational processes with organisations in social movements, including within PDTG'.

Tejiendo Saberes constructs an intentional bridge between theory and practice, in content and form TS developed conditions that emphasised how social movements can generate development alternatives. The basic theory of change is summarised as follows:

A socially (including gender, sexual and intercultural), economically and environmentally just world is only possible through 'real', bottom-up democracy in 
diverse, decolonised nations. This extends to the international 'system', which must also be radically democratised through pressure from progressive social movements around the world, who are the main protagonists in its transformation. Through their resistances they generate alternative knowledges, political proposals, autonomous spaces, and social relations that inspire and forge a new democratic world, including the belief that alternatives are possible and desirable.

- New awareness and alternative practice depends on the availability of spaces and processes that generate feedback, systemic analysis and theory from social struggles. But awareness is also needed within movements and in the general population that the transformation of power relations is a complex and multidimensional affair - thereby requiring ongoing, political, cultural, and epistemological resistance. This can be supported by critical researchers and educators who construct discourses, analyses and proposals for change.

- Key actors in social movements not only provide examples of development alternatives - documented by others - but must also have the capacity to convert their own knowledges and discourse into viable political proposals that influence society and political systems.

The team further developed these ideas as relationships between conditions, including highlighting the importance of 'the state' as an important battleground, and the need to generate dialogical spaces for sharing struggles and knowledge to support a deeper understanding of power relations and the ability to construct proposals from discourses.

This theory of change requires interventions that:

- Diversify the formats of PDTG publications, using language that is more accessible to more people. At the same time create methodological mechanisms and formats to help translate local experiences into useable knowledge for those actors, and other actors and experiences.

- Carry out a more holistic accompaniment process that includes militant research, sharing of research products, and training in systematisation and research.

- Systematise experience, theorise and generate proposals with, from and for social movements.
This will help 'Develop methodological capacities, more trust in our ongoing work with organisations, and improve our own world views as we are exposed to local perspectives'.

These interventions require the capacity within PDTG for facilitating dialogue between key actors in different movements, the capacity to construct knowledge with local actors, and the ability to work with new - more accessible and practical - formats and ways of expressing concepts and language.

\section{Feedback on the theories of change, including individual reflections and positioning}

After each team presented we asked all participants to use different colored Post-It notes to identify the areas of each theory of change that she or he most or least identified with personally, and to register any other questions or comments. Participants requested clarification of TS on whether the methodologies for constructing knowledge 'from below' referred primarily to Noqanchiq's work or to other areas as well. Another participant asked 'What are the techniques, languages and strategies needed to reach these groups?', echoing the scepticism expressed earlier regarding forms of knowledge production. Mar, Diego and Gina personally identified with the TS idea that social movements produce experiences and strategies that generate cultural and political resistance. For Diego this 'Reaffirms my conviction to dispute and construct alternatives to knowledge production processes - for a democratic academy and research practices that are less dogmatic and less instrumental'. Gina adds that this permits multiple expressions of knowledge that contribute to critical theory. But Patty expresses scepticism by stating that the idea of generating critical theory is mere discourse because of the challenges of doing so in a way that is actually meaningful to local actors.

Individual reactions to Noqanchiq's theory of change focused more on questioning the motivations behind the team's strengthening agenda, methodological quandaries and assumptions, for example: 'How do we deal with "systems of domination" at personal and societal levels when we're working with organisations? With what strategies?' And, 'You assume that democratic organisations are more effective - is that really true?' 


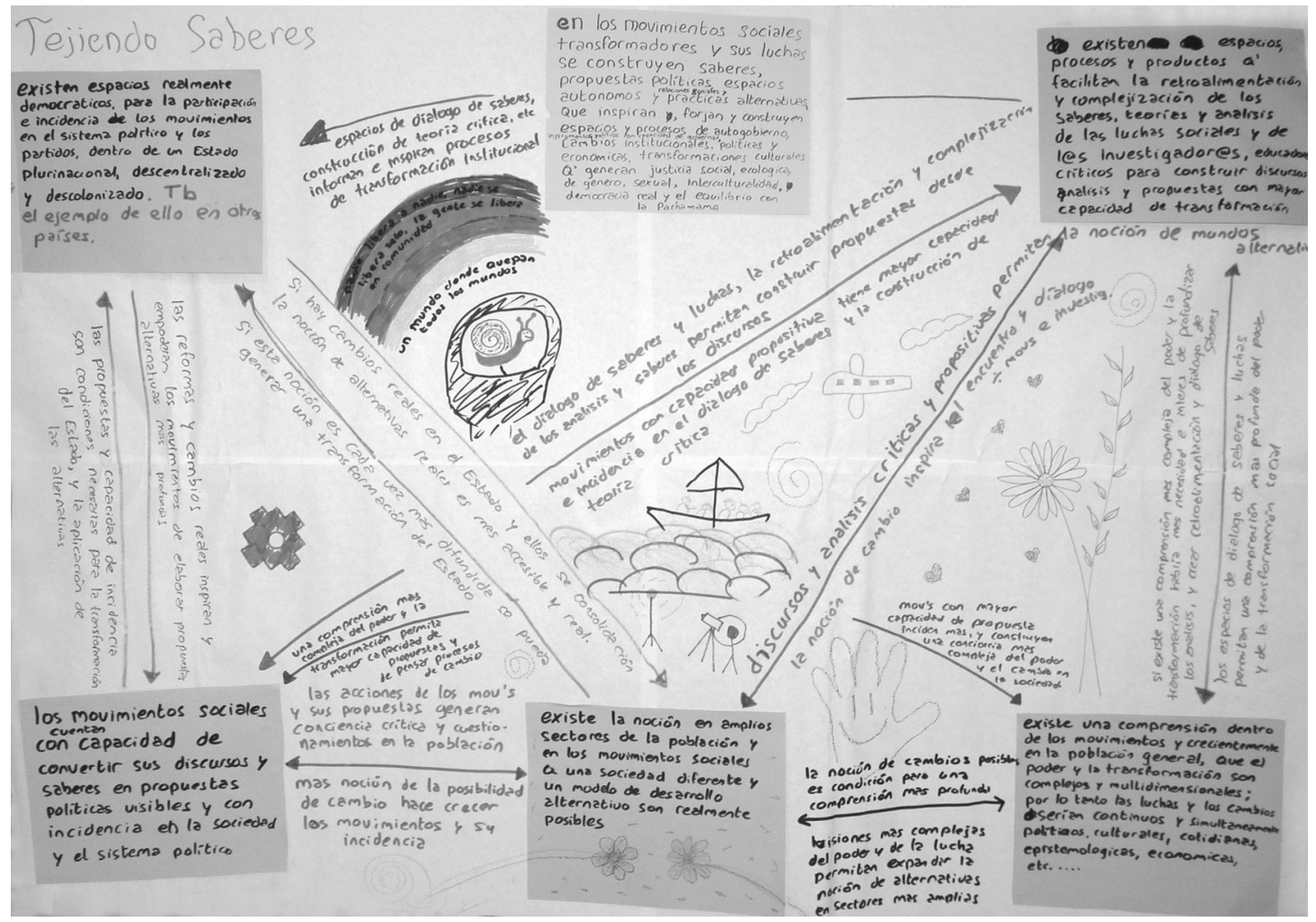

\section{Methodological reflections}

I now share reflections on how the methodology employed was useful in helping PDTG grapple with issues of organisational complexity related to its identity. ${ }^{4}$ This includes discussion on the relevance of the systemic methods as well as the overall Action Research (AR) framework.

\subsection{Strengthening organisations in complex realities Identity emerges in ongoing conversation}

To what extent was PDTG's hybrid identity clarified or strengthened through this process?

Each area heavily challenged their own and each other's programmatic ideas in the sociodrama exercise, and then better substantiated their own area. In the theory of change exercise Tejiendo Saberes essentially carries out a conceptual overhaul that responds to most of the questioning expressed in the sociodrama exercise. This includes developing interventions that cross teamlevel boundaries with Noqanchiq (systematisation), and blurs the line between theoretical production and on-the-ground strengthening. Indeed, the TS theory of change is inclusive of the Noqanchiq theory of change in that it shifts to make its main source of co- constructed theory the on-the-ground actions that are normally the domain of Noqanchiq's strengthening work. Noqanchiq, on the other hand, made an identity shift towards politicising their work and clarifying their overt change agenda as a team. It is now clear that Noqanchiq sees their strengthening as intended to help organisations respond to their leadership challenges as they perceive them, as well as to challenge unjust, anti-diversity and inequitable world views and practices as Noqanchiq sees them. Both teams clearly express a critical militant agenda and both generate conceptual justifications for the need for radical epistemology - including the need to discover new methodologies to support their complex work. But while Noqanchiq's theory of change positions them as an insider social organisation that is part of the specific social movements in which they participate, Tejiendo Saberes still sees itself as an insider/outsider bridge between local resistances and more global social movements, including with critical academia. While the Tejiendo Saberes theory of change is inclusive, Noqanchiq's theory of change does not include this bridging function, and only favours knowledge that is generated to 


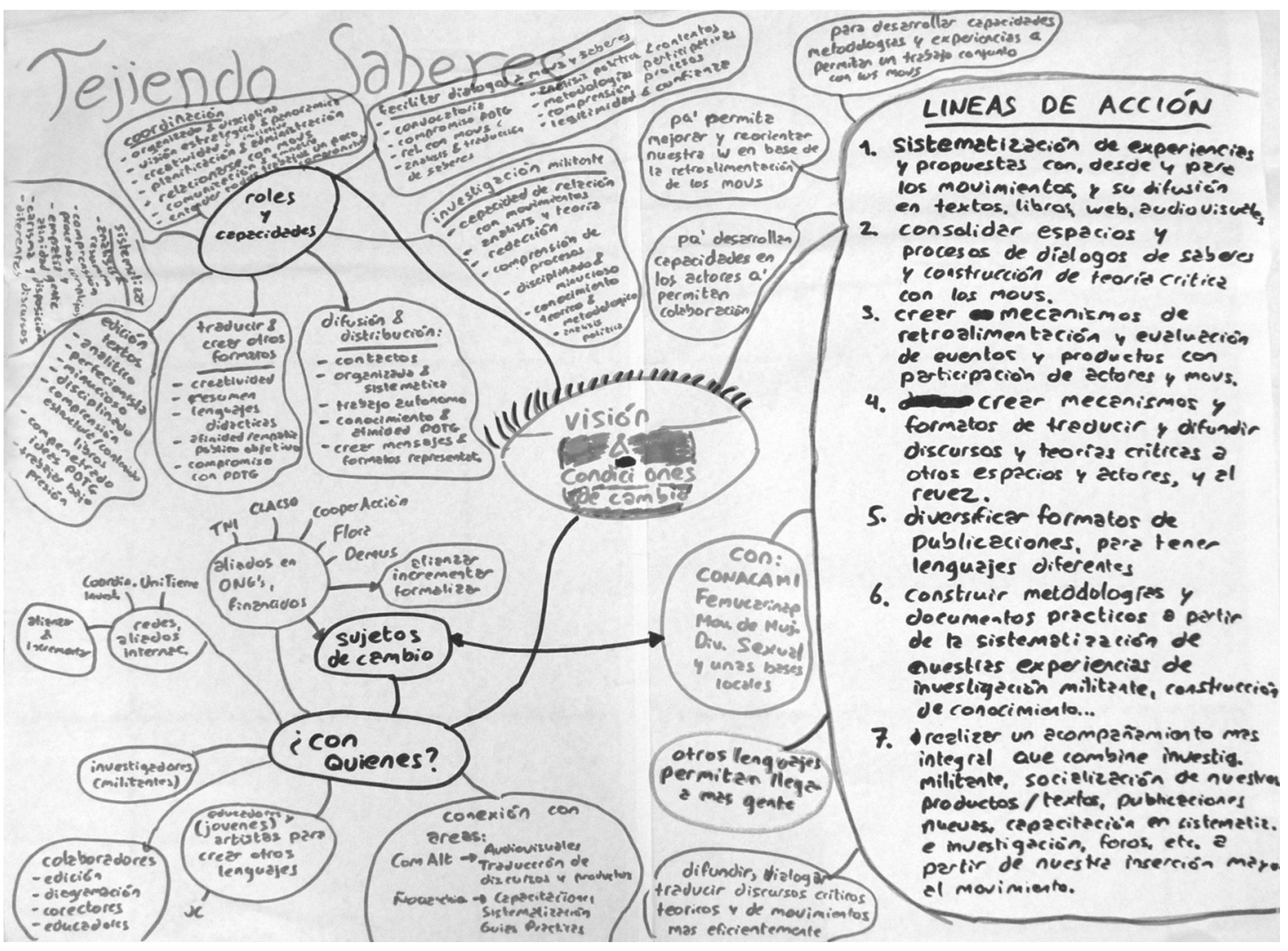

be useful to key actors in social movements.

Notwithstanding, the intentions behind the two theories of change are more explicit and complementary, thus generating more clarity of identity at an overall organisational level.

I believe clarification of organisational identity was due to the fact that the exercises used allowed participants to dive deep into existing organisational conversations in which their interests, motivations and frustrations were close to the surface (Shaw 2002: 39). The subject of the conversations was already relevant and the exercises perhaps provided an accelerator or a 'deep-dive' into those already 'warm issues', including literally building on results from a workshop a month earlier. Then, in long sessions of interaction participants were able to express positions, receive feedback, and adapt (or not) their positions, without any of this positioning having been an explicit part of the exercise. Indeed, it was only upon post-workshop reflection that I realised that the conversation, more than the method, had been the most important part of the process. In these interactions enabling- constraints emerged in conversation which validated some ideas, challenged others, and dynamically introduced new ideas in an iterative process. Although we do not know if the patterns will return to their old form, or if they will inspire some of the actual behaviour changes implicit in the theories of change, we did see evidence of the 'disturbance of repetitive patterns that allows new ones to emerge' (ibid.: 34 ), albeit in the microcosm of a workshop. At this level Shaw's changing conversations theory is helpful in making some sense of these results.

But Shaw's theory does not explain other key methodological elements that helped us make sense out of PDTG's complexity. For that I turn to soft systems thinking.

\section{Soft systems thinking brings world views into contrast and exposes important enabling-constraints}

In both exercises we used methodology to draw (figuratively) a complex picture of a situation in which each team carries out its programmatic work. We then developed simple maps of 'change' conditions and conceptual (non-linear) 
relationships between those conditions, and used the diagrams to generate a structured debate on world views and assumptions on change. The systemic theories of change maps (see Figures 2 and 3 ) and the results from the sociodrama exercise are not final products which offer our best representation of reality; rather, they are epistemological devices that help us structure critical discussion on change. This directly borrows from Checkland's Soft Systems Methodology which also uses systemic drawings to generate debate on the different ways different people see 'systems' in different situations (see Checkland 1981 and 2000; Checkland and Poulter 2006). These maps of conditions, just as Checkland's systems drawings, are epistemological, not ontological in their intentionality, i.e. they are intended to ask better questions of complex situations, not describe reality. In Shaw's language they are props in the drama (Shaw 2002: 28) and not the drama itself. These epistemological devices were used to generate contrasting or additional perspectives that supported perhaps a more intensive interaction than that which might occur in other 'everyday' conversations. For example:

1 The contrast between primary stakeholder expectations and actual PDTG offerings generated internal team introspection and sharp exchanges on programmatic relevance, particularly from Noqanchiq to Tejiendo Saberes.

2 The surfacing of core assumptions and necessary conditions revealed two very distinct, albeit complementary, programmatic world views, which supported an even more intense dialogue.

3 The use of successive methodological approximations in each exercise yielded additional conversation and layers of identity. For example, reflections on mixed motivations of the primary stakeholders, first with Noqanchiq and then with Tejiendo Saberes, only emerge in the post-sociodrama plenary the third moment of that exercise. Tejiendo Saberes highlighting the importance of 'the state' in their theory of change only appears in the relationships between conditions. This highlights the importance of reflective spaces after exercises, and iterative approximations to the issues.

4 The use of Post-It notes also permitted deeper levels of questioning - exposing enabling constraints - to emerge.
In summary, we used these exercises as epistemological devices intended to help ask better questions of complex situations from different perspectives, thus enriching the quality and intensity of the conversation in the workshop. The diagrams, maps, matrices and other artifacts that find their way onto flipcharts are not 'the results' of the workshop, but props used to generate more reflective and meaningful gesturing processes between people.

\subsection{Implications for action research}

Reason articulates action research as 'An emergent process of engagement with worthwhile practice purposes, through many ways of knowing, in participative and democratic relationships' (2006: 189). He presents this as four critical themes where choice has to be exercised to generate quality AR. I now use Reason's four themes to explore some implications for AR from the case presented.

\section{Addressing worthwhile practical purposes with 'the} primacy of the practical'

Reason emphasises that all people are participating actors in their world, i.e. the nature of humans, the way we live and survive is through action. As such, inquiry should have a direct, moral purpose of contributing to people's action in the world - as 'Inquiry in the pursuit of worthwhile purposes for the flourishing of persons, communities and the ecology of which we are all a part' (Reason 2006: 188). Team Noqanchiq strongly supported the idea that locally generated knowledge should be used to support local sense-making processes and challenged the idea of its use in theoretical debates elsewhere. The 'primacy of the practical' (Heron 1996), however, does not imply a narrow focus on practice; rather a congruence of theory and practice that allows us to be more reflective and informed as we act in the world, even as we test our claims of knowledge with evidence generated from practice (Reason 2006: 189). In this sense theory is practical and practice enacts theory, as well as life philosophy (Gramsci 2008). But practice also enacts dominant populationwide patterns of behaviour (Stacey 2007), as highlighted by Noqanchiq's challenging of antidiversity patterns of behaviour within social movements. Here, externally generated theory (as supported by Tejiendo Saberes) may be useful in generating critical awareness that shifts organisational conversations towards more 
equitable practices within social movements, and within PDTG. But whether theory has been generated or not, worthwhile purpose has an emancipatory focus that addresses questions of power and seeks increased experiential sensemaking abilities amongst participants (Reason 2006: 193). In this case an inclusive theory of change that steers away from either-or theory/ practice perspectives would seem to be relevant in supporting PDTG in grappling with their complexity.

\section{Participatory and democratic processes}

At a methodological level AR should be participatory for the practical reason that those who experience challenges in their practice are the most knowledgeable of those challenges (Reason 2006: 189). But there are also ethical and political considerations which speak to people's right and ability to contribute to processes and decisions that affect their lives (Altrichter et al. 2002; Fals Borda 2001; Greenwood and Levin 2007; McTaggart 1991). As such 'Action research is a participative and democratic process that seeks to do research with, for, and by people; to redress the balance of power in knowledge creation; and to do this in an educative manner that increases participants' capacity to engage in inquiring lives' (Reason 2006: 189). These concepts were central to both TS and Noqanchiq's challenge of theory-generating processes conducted by outside experts and Ñoqanchiq's open questioning of its own intentions to generate democratic, collaborative and equitable relationships with the organisations with which they work. This led to open questioning about the real needs and motivations of the organisations PDTG accompanies, including surfacing the possibility that some organisations simply might prefer to outsource deeper inquiries and not be interested in concepts of AR. In its theory of change TS shifts its conversation to include a participatory, democratic world view (e.g. organisations have the capacity to process their own knowledges...), and in its programmatic offering: 'Systematise experience, theorise and generate proposals with, from and for social movements'.

'Worthwhile practical purpose' and 'participatory and democratic processes' both have implications on the role of the facilitator and the balance between action and research, i.e. in the relative emphasis placed on the practical transformation vis-à-vis the advancement of more general knowledge or theory (Huxham and Vangen 2003: 384). This then affects whether organisational participants are aware that they are participating in research beyond the practical action or learning they seek (ibid.: 386). At one extreme, perhaps, is action taken in an organisation by a researcher in which the organisation only seeks practical improvements, while the researcher also desires to generate more general, theoretical knowledge. This is still AR to the researcher, but to the organisation it is simply practical 'action'. At the other end of the spectrum are AR definitions that seek practical action and knowledge generation but with a highly participative and democratic social change world view (e.g. see Fals Borda 2001; Greenwood and Levin 2007; McIntyre 2008; McTaggart 1991). In the AR of which this workshop was a part, although the methods used allowed for a good amount of content control by the participants, method control and the research focus was mostly retained by the facilitators. A more participatory and democratic process would require a shift from the researcher-controlled extreme expressed by Huxham and Vangen towards AR with a more overt participatory social change agenda, including more shared control of the methodology.

\section{An emergent, conversational developmental form}

If $\mathrm{AR}$ is intimately bound up in people's lives and work (Reason 2006: 189), and change emerges in the interplay of the desires, intentions and actions of all of the lives and work of people in a given social setting (Stacey 2007: 303), then AR design must be flexible and allow for the possibility that questions and purposes may change as new knowledge as situations emerge (Reason 2006: 197). This implies methodology that is designed emergently along the way, rather than predesigned linear programmes with 'hard and fast methods' (ibid.). But if complex forms of organisation exist and are potentially transformed in organisational conversations (Shaw 2002: 10), then strengthening processes should encourage people in their real life situations to carry out the conversations that are relevant to them. The facilitator's role would need to shift from that of the cybernetic steersman who keeps the ship moving forward according to plan, to that of an opportunistic improviser that hands over methodological control and responsibility and supports people to give into what might be emerging without too fixed an idea of where each move might lead (Shaw 2002: 42). 
To do so Shaw favours a more open conversational approach with method playing a less conspicuous role and facilitators mainly helping to lightly move conversations forward in ways that allow for participants to reflect on and address enabling-constraints. Our workshop had more highly structured methods than Shaw appears to favour, but the methods were still primarily used as 'props in the drama' (ibid.: 28) that allowed us to enter into intensive conversation about issues of deep importance to many of the participants. In order to generate rich conversation in future processes an even more emergent conversational design which consciously keeps overly structured method out of the way might more effectively tap people's interests and allow for naturally entering the flow of organisational complexity.

\section{Encompassing many ways of knowing}

At the core of the debate between TS and Noqanchiq was the search for knowledge that would be relevant to local realities (i.e. in content), in languages that people find meaningful (i.e. in form), and via processes of construction that in and of themselves help people make sense out of their real life challenges, intentions and desires. This implies extending epistemologies beyond narrow ways of seeing and acting in the world (Reason 2006: 189). Heron offers a pyramid of 'ways of knowing' as four broad categories, each building on the levels beneath (1999: 122). At the base of the pyramid is experiential knowing which represents the way we come to know through daily lived experience, including the energy, people, places processes and things we take in through our senses and intuition (ibid.). Then, through presentational knowledge (e.g. via graphics, drama, music, poetry, storytelling, and other nondiscursive means) we reveal our tacit or intuitive grasp of the significance of experience (1996: 41, 1999: 122). Presentational/ aesthetic forms of expression can effectively represent complex patterns of relations and tacit knowledges (e.g. saberes), while discursive forms favour explicit knowledge (Seeley and Reason 2008: 4), often in the form of propositions. Propositional knowing is expressed in statements that 'something is the case' (Heron 1999: 122), often in terms of descriptive and theoretical statements, i.e. the traditional version of research findings (Heron 1996: 41). And at the top of the pyramid practical knowing shows we know how 'to do' something, demonstrating our skills and competencies. As a whole the four levels are all experiential and people tacitly interweave them in many ways in everyday life (Heron and Reason 2008: 367). Knowing in action research is said to be more valid when grounded in experience, expressed through our stories, images and full range of senses, enriched through theories which make sense to us, and expressed in worthwhile action in our lives (ibid.).

The selection of sociodrama - a presentational form of knowing and communication - was an intentional attempt to use subjective, multicognitive methods to generate intersubjective understandings and help reveal deeper identities and motivations for change than are possible with other methods. Participants used the sociodramas to revive prior experiences and improvise upon them to show real frustration in the case of Noqanchiq, and aspirations of new theory/practice hybrids in the case of TS. Inspired by the practice of Reflect-Action ${ }^{6}$ these senticuerpo-pensante (SCP) (emotion/embodiment (touch)/thinking) methods use emotions, sensations and thoughts to better understand identities, motivations and barriers to change at personal, organisational and societal levels (Giles Macedo and Abad 2009: 1-2). The sociodramas themselves used complex responsive processes of relating to reveal issues that might not have emerged as easily through other methods.

Presentational knowing, i.e. how we re-'present' life experience and intuition, is not just a bridge between experience and propositional knowing but is valuable in its own right (Seeley and Reason 2008: 4) - informing experiential and propositional knowing as well as being informed by them (ibid.: 19). In other words presentational knowing that is only used as a creative tactic to enhance thinking for 'real' propositional knowledge remains within the hegemonic European critical world view, with rational analysis positioned as the apex of sense-making. ${ }^{7}$ For this workshop this begs the question of whether we carried out sociodramas as creative expressions of communication as a tactic to generate better inputs for more rational analysis that comes in a theory of change diagram. Although the theory of change process as we conceived of it was also a form of presentational knowledge, it culminated in a product that expresses propositions about the way things are and should be. 
My response is that I am not yet sure of the answer. It is possible that we were guided by an implicit idea that the end goal in any process is 'the practical and polished thing'; therefore all creative process is ultimately leading to a rational strategic moment, even if that moment seeks out 'results' that are less linear and behaviours that are more tolerant of ambiguity and more respectful of different understandings of meaningfulness. But at the same time I am clear that we use SCP methods to generate transformational, embodied reflection that generates less fear, more empathy, and more consciousness of ourselves as subjects of

\section{Notes}

1 Different theories on power relationships highlight that much of what constrains people's future possibilities is the very fact that they are excluded from the ability to engage in conversation and other meaningful action (e.g. see Clegg et al. (2006); Gaventa (2006); Lukes (2005)). The desires and intentions of people in power might manifest themselves as a decision to keep certain people away from the table, or keep their issues off the agenda for example. Similarly, cultural norms (including local organisational culture) may validate certain types of participation more than others, or certain types of knowledge over others (Gaventa and Cornwall 2008), thereby making transformation via communicational processes improbable to say the least. 'Complex Responsive Processes' does not assume that there is an accessible arena for conversation in which people are able to represent their interests in a fair setting, including confronting power constraints effectively. Rather, it assumes that the very decision to exclude, including multiple conscious and unconscious actions that generate exclusion, are also communicational - even as they exclude some in the process (sometimes very intentionally). While this may be the case, the problematic effect of this exclusion is perhaps too significant to try to explain with communicational theory. Given the fact that the focus of this article was a convened workshop I will not explore this issue further, but will conclude by saying that power theories do raise important issues that are not able to be fully explained through this communicational theory. transformation. Complexity theorists have shown how novel patterns of activity have a better chance of emerging when agents differ sufficiently from each other, 'so displaying diversity' (Stacey 2007; Stacey et al. 2000), which surely must include diversity in ways of knowing. If action research is to help us make sense out of our complex realities then methods are needed which tap into locally relevant cultural systems of meaning that reflect the whole person, and continually invite us to reflect on our own world views that may constrain or enable our ability to honor diverse 'saberes' (Rodriguez Ibañez 1997) over the search for one 'true' knowledge.

2 Saberes are knowledges rooted in cultural systems of meaning that take into account tacit sensibilities that we use to make sense of our worlds in specific settings. They reflect the whole person (Rodriguez Ibañez 1997: 113) and as culturally grounded systems that are meaningful as part of one's being, they are neither 'validate-able' nor refutable through scientific knowledge.

3 What is reality, how do we know and what can we do to find out more about it? These questions roughly describe the important relationship between the concept of methodology, and two terms that are not commonly used by most practitioners I have worked with, ontology and epistemology. Ontology refers to different people's understanding of reality. Whatever we perceive to be real when we come into contact with any thing or situation, is ontological. Epistemology refers to the ways in which we know about what is real, from formal processes such as research and studying, to everyday intuitive 'life methods' of living, working and experiencing. Methodology refers to the methods (and principles of method) that we use to actually do the (epistemological) 'finding out' about realities (ontology).

4 These reflections are my own intended to look for possible connections between Shaw's 'changing conversations' theory and these two workshop moments. Due to space limitations, they do not draw from formal evaluative moments with PDTG.

5 The Alternative Communication theory of change (not presented here), on the other hand, was heavily confronted by the participants, and was later dissolved as a team.

6 Reflect-Action (RA) is an offshoot of 'Reflect' which was originally developed by the UK 
NGO ActionAid as a way to link adult literacy to empowerment by combining Friereian adult literacy approaches with Participatory Rural Appraisal (PRA) (Archer 2007).

\section{References}

Altrichter, H.; Kemmis, S.; McTaggart, R. and Zuber-Skerritt, O. (2002) 'The Concept of Action Research', The Learning Organization 9: 125-131

Archer, D. (2007) 'Seeds of Success are Seeds for Potential Failure: Learning from the Evolution of Reflect', in K. Brock and J. Pettit (eds), Springs of Participation: Creating and Evolving Methods for Participatory Development, Rugby: Practical Action Publishing

Baser, H. and Morgan, P. (2008) 'Capacity, Change and Performance: Study Report', in ECDPM (ed.), Capacity, Change and Performance, Maastricht: European Centre for Development Policy Management (ECDPM)

Burns, D. (2007) Systemic Action Research: A Strategy for Whole System Change, Bristol: Policy Press

Chambers, R. (2010) Paradigms, Poverty and Adaptive Pluralism, IDS Working Paper, Brighton: IDS

Chambers, R. (1997) Whose Reality Counts: Putting the First Last, London: ITDG Publishing

Checkland, P. (2000) 'Soft Systems Methodology: A Thirty Year Retrospective', Systems Research and Behavioral Science 17: S11-58

Checkland, P. (1981) Systems Thinking, Systems Practice, Chichester: John Wiley \& Sons Inc.

Checkland, P. and Holwell, S. (1998) Information, Systems and Information Systems: Making Sense of the Field, Chichester: John Wiley \& Sons Inc.

Checkland, P. and Poulter, J. (2006) Learning for Action: A Short Definitive Account of Soft Systems Methodology and its use for Practitioners, Teachers and Students, Chichester: John Wiley \& Sons Inc.

Churchman, C.W. (1979) The Systems Approach and its Enemies, New York: Basic Books

Clegg, S.; Courpasson, D. and Phillips, N. (2006) Power and Organizations, Los Angeles: Sage Publications

de Echave, J.; Hoetmer, R. and Panez, M.P. (eds) (2009) Minería y Territorio en el Perú: Conflictos, Resistencias y Propuestas en Tiempos de Globalización [Mining and Territory in Peru: Conflicts, Resistances and Proposals in Times of Globalization], Lima: Programa Democracia y Transformación Global (PDTG)

de Sousa Santos, B. (2006) Conocer Desde el Sur: Para una Cultura Política Emancipatoria [Knowing
7 Many thanks to Jethro Pettit for encouraging me to reflect further on this important issue in this article.

from the South: For an Emancipatory Political Culture], Lima: Programa Democracia y Transformación Global (PDTG)

Escobar, A. (2010) Una Minga para el Postdesarrollo: Lugar, Medio Ambiente y Movimientos Sociales en las Transformaciones Globales [A Collective for PostDevelopment: Place, Environment and Social Movements in Global Transformations], Lima: Programa Democracia y Transformación Global (PDTG)

Fals Borda, O. (2001) 'Participatory (Action) Research in Social Theory', in P. Reason and H. Bradbury (eds), The Sage Handbook of Action Research: Participative Inquiry and Practice, London: Sage

Flood R.L. (1999) Rethinking the Fifth Discipline: Learning within the Unknowable, New York: Routledge

Flood, R.L. (1988) 'Situational Complexity, Systems Modelling and Methodology', Transactions of the Instititute of Measurment and Control 10.7

Gaventa, J. (2006) 'Finding the Spaces for Change: A Power Analysis', IDS Bulletin 37.6: 23-33

Gaventa, J. and Cornwall, A. (2008) 'Power and Knowledge', in P. Reason and H. Bradbury (eds), The Sage Handbook of Action Research: Participative Inquiry and Practice, 2nd edition, London: Sage

Giles Macedo, J.C. and Abad, E. (2009) ¿Qué es Reflect-Acción? [What is Reflect Action?], Lima: La Red de Reflect Acción de Lima Perú

Gramsci, A. (2008) Introducción a la Filosofia de la Praxis: Selección y Traducción de J. Solé Tura [An Introduction to the Philosophy of Praxis], Sevilla: Editorial Doble J.

Greenwood, D.J. and Levin, M. (2007) Introduction to Action Research: Social Research for Social Change, Thousand Oaks CA: Sage Publications Heron, J. (1999) The Complete Facilitator's Handbook, London/Philadelphia: Kogan Page

Heron, J. (1996) 'Quality as Primacy of the Practical', Qualitative Inquiry 2: 41-56

Heron, J. and Reason, P. (2008) 'Extending Epistemology within a Co-operative Inquiry', in P. Reason and H. Bradbury (eds), The Sage Handbook of Action Research: Participative Inquiry and Practice, 2nd edition, London: Sage

Hoetmer, R. (ed.) (2009) Cultura, Estado y Movimientos Sociales [Culture, the State and Social 
Movements], Lima: Programa Democracia y

Transformación Global (PDTG)

Huxham, C. and Vangen, S. (2003) 'Researching Organizational Practice through Action Research: Case Studies and Design Choices', Organizational Research Methods 6: 383-403

Jackson, M.C. (2003) Systems Thinking: Creative Holism for Managers, Chichester, John Wiley and Sons Inc.

Kaplan, A. (1999) The Developing of Capacity, Community Development Resource Association (CDRA)

Land, T.; Hauck, V. and Baser, H. (2009) 'Capacity Development: Between Planned Interventions and Emergent Processes. Implications for Development Cooperation', in ECDPM (ed.), Capacity Change and Performance, Policy Management Brief, Maastricht: European Centre for Development Policy Management (ECDPM)

Lukes, S. (2005) Power: A Radical View, Palgrave Macmillan

McIntyre, A. (2008) 'Participatory Action Research', in S. University (ed.), Qualitative Research Methods Series

McTaggart, R. (1991) 'Principles for Participatory Action Research', Adult Education Quarterly 41.20

Midgley, G. (2000) Systemic Intervention: Philosophy, Methodology, and Practice, New York: Kluwer Academic/Plenum Publishers

Mintzberg, H. and Waters, J.A. (1985) 'Of Strategies, Deliberate and Emergent', Strategic Management Journal 6: 257-72

Mintzberg, H.; Ahlstrand, B. and Lampel, J. (2009) Strategy Safari: Your Complete Guide through the Wilds of Strategic Management, 2nd edition, Harlow: Prentice Hall

Morgan, G. (2006) Images of Organization, Thousand Oaks: Sage

Morgan, P. (2005) The Idea and Practice of Systems Thinking and Their Relevance for Capacity Development, Maastricht: European Centre for Development Policy Management (ECDPM)

Ramalingam, B. and Jones, H. (2008) Exploring the Science of Complexity: Ideas and Implications for Development and Humanitarian Efforts, ODI Working Paper 285, 2nd edition
Reason, P. (2006) 'Choice and Quality in Action Research Practice', Journal of Management Inquiry 15: 187-203

Rodriguez Ibañez, M.L. (1997) La Construcción Colectiva del Conocimiento en la Educación Popular: Desafios Actuales en Contextos Culturales AndinoBolivianos [Collective Construction of Knowledge in Popular Education: Current Challenges in AndeanBolivian Contexts], La Paz, Bolivia: Procep; Cenprotac; Colectivo CEAAL (Consejo de Educación de Adultos de América Latina) Bolivia; MEPB (Movimiento Educadores Populares de Bolivia)

Seeley, C. and Reason, P. (2008) 'Expressions of Energy: An Epistemology of Presentational Knowing', in P.L.A.J. Rumbold (ed.), Knowing Differently: Arts-Based and Collaborative Research, New York: Nova Science Publishers Inc.

Shaw, P. (2002) Changing Conversations in Organizations: A Complexity Approach to Change, London/New York: Routledge

Snowden, D.J. and Boone, M.E. (2007) 'A Leader's Framework for Decision Making', Harvard Business Review: 69-76

Stacey, R.D. (2007) Strategic Management and Organizational Dynamics: The Challenge of Complexity, Harlow: Pearson Educational Ltd

Stacey, R.D.; Griffin, D. and Shaw, P. (2000) Complexity and Management: Fad or Radical Challenge to Systems Thinking?, London/New York: Routledge

Taylor, P. and Clarke, P. (2008) Capacity for a Change, Brighton: IDS

Vargas Valente, V. (2008) Feminismos en América Latina: Su Aporte a la Política y a la Democracia [Feminisms in Latin America: Their Contribution to Politics and Democracy], Lima: Programa Democracia y Transformación Global (PDTG) von Bertalanffy, L. (1968) General System Theory: Foundations, Development, Applications, New York: George Braziller

Zibechi, R. (2007) Autonomías y Emancipaciones: America Latina en Movimiento [Autonomies and Emancipations: Latin America in Movement], Lima: Programa Democracia y Transformación Global (PDTG) 